\title{
A CRITICAL APPRAISAL OF THE PLANT HEALTH (PHYTOSANITARY) BILL'S COMPLIANCE WITH THE SALIENT ASPECTS OF THE WORLD TRADE ORGANIZATION (WTO) AGREEMENT ON THE APPLICATION OF SANITARY AND PHYTOSANITARY MEASURES
}

Clive Vinti

LLB LLM

Lecturer, Public Law

University of the Free State

\section{SUMMARY}

This paper juxtaposes the long-mooted Plant Health (Phytosanitary) Bill with its corollary, the World Trade Organization (WTO) Agreement on the Application of Sanitary and Phytosanitary Measures (SPS). Firstly, this paper finds that the Bill creates an ambiguity by including in the definition of "phytosanitary measures", those "measures, regulations or procedures that limit the economic impact of regulated non-quarantine pests", without any guidance on the relevant factors to be considered in this regard. Secondly, it is found that the Bill explicitly establishes the requirement that the new phytosanitary regime is based on "scientific principles". Thirdly, the paper argues that the Bill also establishes the general rule that makes "sufficient science" the basis of any phytosanitary measure in conformity with South Africa's core obligations under the SPS. Fourthly, this paper finds that the Bill contravenes Article 5.7 of the SPS in that it provides for the implementation of the so-called "emergency and provisional measures" by the competent authority as an exception to the "sufficient science" rule, without any of the necessary safeguards created by Article 5.7. Lastly, the paper finds that the Bill has unduly shifted the primary burden of preventing the entry and establishment of a pest, from the competent authority to the "user of land".

\section{INTRODUCTION}

South Africa is a signatory to the World Trade Organization Agreement on the Application of Sanitary and Phytosanitary Measures. ${ }^{1}$ The SPS is the

\footnotetext{
Hereinafter "the SPS". GN 889 in GG 38102 of 2014-10-17 (Plant Health [Phytosanitary]
} Policy for South Africa) (hereinafter "Plant Health Policy") 5. The SPS entered into force on 
"constitutive text" of the WTO that establishes the requirements for all sanitary and phytosanitary measures that may, directly or indirectly, affect international trade. ${ }^{2}$ In pursuance of its obligations under the SPS, South Africa has drafted the Plant Health (Phytosanitary) Bill. ${ }^{3}$ The Agricultural Pests Act (hereinafter "the Act") was meant to "prevent" and "combat" establishment of pests. ${ }^{4}$ However, the Act and some of its regulations were promulgated prior to the advent of the SPS, and thus inevitably, do not adequately address the requirements of the SPS. ${ }^{5}$ Therefore, the Bill is meant to give effect to South Africa's obligations under the SPS. ${ }^{6}$ In essence, the Bill primarily purports to repeal those sections of the Act that deal with phytosanitary matters in order to improve the regulation of phytosanitary measures in respect of trade. ${ }^{7}$ More specifically, the Bill purports to repeal section 3(1) of the Act in so far as it relates to plants ${ }^{8}$ and the whole of section 6 of the Act, which gives details of the control measures that must be used to prevent and combat pests. ${ }^{9}$ This means if the Bill was passed and promulgated, then the Act would still be in effect in relation to other matters it regulates but would no longer be applicable to phytosanitary measures in respect of trade.

Consequently, this paper assesses the compatibility of the Bill with the salient aspects of the SPS. This analysis is conducted through a critical analysis of the SPS, relevant case law and the relevant legislation. This paper argues that the Bill creates an ambiguity by including in the definition of "phytosanitary measures", those "measures, regulations or procedures that limit the economic impact of regulated non-quarantine pests", without any guidance on the relevant factors to be considered in this regard. Secondly, it is found that the Bill explicitly establishes the requirement that the new phytosanitary regime is based on "scientific principles" in line with the SPS. Thirdly, it is also found that the Bill establishes the general rule that makes "sufficient science" the basis of any phytosanitary measure in conformity with South Africa's core obligations under the SPS. Fourthly, this paper finds that the Bill contravenes Article 5.7 of the SPS in that it provides for the implementation of the so-called "emergency and provisional

1 January 1995 as part and parcel of the Marrakesh Agreement which established the World Trade Organization.

2 Art 1.1 of the SPS. See Vinti and Makapela "Peeling the Orange: A Critical Assessment of the Legality of the European Union Sanitary and Phytosanitary Measures Regime against Citrus Produce from South Africa" 201637 Obiter 449456.

3 Hereinafter "the Bill". S 35 of the Bill.

4 See long Title of the Agricultural Pests Act 36 of 1983, which specifies the purpose of the Act. See also, s 6 of the Bill on the measures that can be employed to "prevent" and "combat" pests which includes the destruction of plants; the cleansing or destruction of plants or any particular thing infected with pathogens or insects and the keeping, planting or cultivation of plants.

5 Plant Health Policy 11.

6 See s 35 of the Bill. See also GN 1489 in GG of 2016-12-02: Agricultural Pests Act (36/1983): Publication of explanatory summary of the Plant Health (Phytosanitary) Bill 4.

7 Preamble to the Bill. See also GN 1489 in GG of 2016-12-02: Agricultural Pests Act (36/1983): Publication of explanatory summary of the Plant Health (Phytosanitary) Bill 4.

8 S 3(1) of the Act essentially provides that no person shall import into the Republic, any plant, pathogen, insect, exotic animal, growth medium, infectious thing, honey, beeswax, or used apiary equipment. See the Schedule to the Bill.

9 See s 6(2) of the Act. See the Schedule to the Bill. 
measures" by the competent authority as an exception to the "sufficient science" rule, without any of the necessary safeguards created by Article 5.7. Lastly, the paper finds that the Bill has also unwittingly contrived unduly to shift the primary burden of preventing the entry and establishment of a pest, from the competent authority to the "user of the land".

\section{CRITICAL ANALYSIS OF THE BILL'S COMPLIANCE WITH THE SALIENT ASPECTS OF THE SPS}

\section{An assessment of the definitions of selected aspects in the Bill and the SPS}

According to the Bill, "phytosanitary measures" means those measures, regulations or procedures as provided for by the Act, having the purpose to prevent the introduction or spread of quarantine pests or to limit the economic impact of regulated non-quarantine pests. ${ }^{10}$ A "quarantine pest" means a pest of potential economic significance to the area endangered thereby and not yet present there or present but not widely distributed and being officially controlled. ${ }^{11}$ On the other hand, a "regulated non-quarantine pest" means a non-quarantine pest whose presence in plants for planting affects the intended use of those plants with an economically unacceptable impact and which is therefore regulated within South Africa. ${ }^{12}$ It is presumed that the lists of pests that will fall under the classes of either a "quarantine pest" or a "regulated non-quarantine pest" will be published as required by section 17(2), only after a pest risk analysis has been conducted as per section $17(1)$ of the Bill. Needless to say, the identity of these pests will only be revealed once the Bill is promulgated. A "pest risk analysis" means the process of examining biological or other scientific and economic evidence to establish whether a pest should be regulated and the strength of any phytosanitary measures to be taken against it. ${ }^{13}$

To the contrary, the definition in the SPS is more detailed and clearer in that it defines a "sanitary or phytosanitary measure" as any measure applied: to protect animal or plant life or health within the territory of the Member from risks arising from the entry, establishment or spread of pests, diseases, disease-carrying organisms or disease-causing organisms; to protect human or animal life or health within the territory of the Member from risks arising from additives, contaminants, toxins or disease-causing organisms in foods, beverages or feedstuffs; to protect human life or health within the territory of the Member from risks arising from diseases carried by animals, plants or products thereof, or from the entry, establishment or spread of pests; or to prevent or limit other damage within the territory of the Member from the entry, establishment or spread of pests. ${ }^{14}$ In this respect, it can then be seen

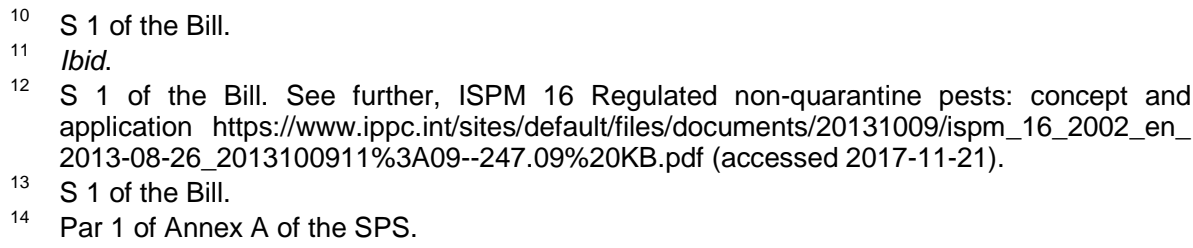


that the Bill complies with the SPS in that it even caters for measures employed to "prevent or limit other damage (author's own emphasis) caused by the entry, establishment or spread of pests" because it includes measures to limit the "economic impact of regulated non-quarantine pests". However, the Bill and the SPS offer little guidance on what constitutes "economic impact". This means that the competent authority may be requested to conduct an amorphous test on the "economic impact of regulated non-quarantine pests". Secondly, the ambiguous "economic impact" threshold may be susceptible to manipulation by a competent authority, which may use "phytosanitary measures" as instruments to implement the disguised discrimination against imports. It has been suggested that developed countries, due to consumer demands and technological capacity, often establish very high levels of protection, as evinced by the stern SPS requirements. ${ }^{15}$ Thus, it has been submitted that many legitimate SPS measures exist that are in conformity with the requirements of the agreement, yet present significant barriers to market access for developing countries. ${ }^{16}$ The ambiguous "economic impact" threshold in the Bill could be seen as a barrier to market access.

Guidance on the "economic impact" threshold could still yet be found through the avenue of Article 5.3 of the SPS. Article 5.3 of the SPS provides that in assessing the risk to animal or plant life or health and determining the measure to be applied for achieving the appropriate level of sanitary or phytosanitary protection from such risk, ${ }^{17}$ Members must take into account as relevant economic factors: (author's own emphasis) the potential damage in terms of loss of production or sales in the event of the entry, establishment or spread of a pest or disease; the costs of control or eradication in the territory of the importing Member; and the relative costeffectiveness of alternative approaches to limiting risks. ${ }^{18}$ It is suggested that the factors listed in Article 5.3 of the SPS, proffer cogent factors that could go a long way in ascertaining the "economic impact" threshold in the determination of what measures constitute "phytosanitary measures" in South Africa.

However, South Africa must ensure that such measures are not more trade restrictive than required to achieve their ALOP, taking into account technical and economic feasibility. ${ }^{19}$ Article 5.6 of the SPS and, in particular, the footnote to this provision, patently creates a three-pronged test to establish a contravention of Article 5.6. ${ }^{20}$ The three elements of this test under Article 5.6 are that there is a SPS measure which: first, is reasonably available taking into account technical and economic feasibility; second, achieves the Member's appropriate level of sanitary or phytosanitary protection; and third, is significantly less restrictive to trade than the SPS

15 Prevost "Operationalising Special and Differential Treatment of Developing Countries under the SPS Agreement" 200530 SAYIL 8290.

16 Ibid.

17 Hereinafter "the ALOP".

18 Art 5.3 of the SPS.

19 Art 5.6 of the SPS.

20 WTO Appellate Body Report, Australia Measures affecting Importation of Salmon WT/DS18/AB/R (hereinafter "Appellate Body Report, Australia Salmon"), adopted 6 November 1998, par 194. 
measure contested. ${ }^{21}$ These three elements are cumulative in the sense that, to prove inconsistency with Article 5.6, all of them have to be complied with. ${ }^{22}$ If any of these elements were not fulfilled, the impugned measure would be in conformity with Article 5.6. ${ }^{23}$ Also, if the level of protection established by the proposed alternative meets or exceeds the ALOP, then assuming that the other two requirements in Article 5.6 are met, the importing Member's SPS measure is more trade restrictive than necessary to achieve its desired level of protection. ${ }^{24}$ Thus, if there is no alternative measure available, having due consideration of technical and economic feasibility, or if the alternative measure fails to achieve the Member's ALOP, or if it is not significantly less trade restrictive, the impugned measure would comply with Article 5.6. ${ }^{25}$ For purposes of Article 5.6, a measure is not more trade restrictive than required unless there is another measure, reasonably available taking into account technical and economic feasibility, that achieves the appropriate level of sanitary or phytosanitary protection and is significantly less restrictive to trade. ${ }^{26}$ It can be argued that the amorphous "economic impact" threshold of the Bill exceeds the ALOP and thus fails the three-pronged test of Article 5.6 of the SPS.

A glaring anomaly of the Act was that it failed to create a specific regulatory body that monitors compliance with the SPS phytosanitary regime. ${ }^{27}$ The Bill empathically addresses this issue, which establishes the National Plant Protection Organization of South Africa ${ }^{28}$ in compliance with South Africa's obligations under the SPS. ${ }^{29}$ The pertinent functions of the NPPOZA include, inter alia, notifying trading partners regarding noncompliance with phytosanitary import requirements; distributing Plant Health information regarding regulated pests and any other phytosanitary matters that are of public interest; and notifying other countries about the Republic's phytosanitary measures, regulations, requirements and legislation. ${ }^{30}$ This means that the Bill now complies with South Africa's obligations in the SPS in relation to the publication of regulations and notification procedures in respect of its trading partners and interested parties. ${ }^{31}$

Contrary to its obligations under the SPS, the Act is silent on the concepts of "pest free areas" and "areas of low pest prevalence". The SPS provides that Members shall recognise the concepts of "pest or disease-free areas" and "areas of low pest or disease prevalence". ${ }^{32}$ Determination of such

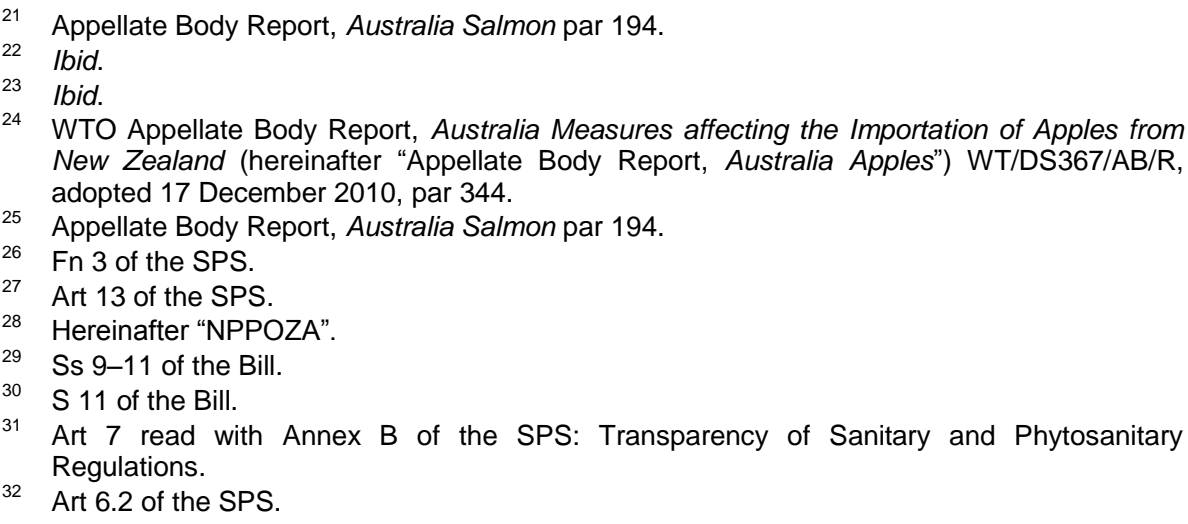

WTO Appellate Body Report, Australia Measures affecting the Importation of Apples from New Zealand (hereinafter "Appellate Body Report, Australia Apples") WT/DS367/AB/R, adopted 17 December 2010, par 344.

25 Appellate Body Report, Australia Salmon par 194

26 Fn 3 of the SPS.

Art 13 of the SPS.

Hereinafter "NPPOZA".

Ss 9-11 of the Bill.

$\mathrm{S} 11$ of the Bill.

Art 7 read with Annex B of the SPS: Transparency of Sanitary and Phytosanitary Regulations.

32 Art 6.2 of the SPS. 
areas shall be based on factors such as geography, ecosystems, epidemiological surveillance, and the effectiveness of sanitary or phytosanitary controls. ${ }^{33}$ To address these gaps in the Act, the Bill recognises for the first time in South Africa, the concept of the "pest free area" and "an area of low pest prevalence". The Bill mimics the SPS, by defining a "pest free area" as an area in which a specific pest does not occur as demonstrated by scientific evidence and in which, where appropriate, this condition is being officially maintained. ${ }^{34}$ In tandem with the SPS, the Bill explicitly requires that a determination of a "pest free area" must be made based on "scientific evidence" and it saddles the competent authority with the duty to monitor this determination. The Bill also provides for a specific process for the "establishment and declaration" of a pest free area: first, the executive officer must be satisfied through surveillance that a specific pest is not present in the area; second, the adoption of phytosanitary measures to establish and maintain a pest free area; and third, the institution of a surveillance programme to verify that the pest free status is maintained. ${ }^{35}$

Furthermore, in the SPS, an "area of low pest or disease prevalence" is an area, whether all of a country, part of a country, or all or parts of several countries, as identified by the competent authorities, in which a specific pest or disease occurs at low levels that is subject to effective surveillance, control or eradication measures. ${ }^{36}$ The definition of the "area of low pest prevalence" in the Bill is identical to that in the SPS. ${ }^{37}$ However, the Bill is more instructive to interested parties than the SPS in that it also expressly provides for the procedure to be followed for the declaration of an "area of low pest prevalence". In essence, the executive officer must first, be satisfied that a regulated pest occurs at low levels in an area; second, adopt phytosanitary measures to establish and maintain an area of low pest prevalence; and third, institute a surveillance programme to verify that the pest levels remain low. ${ }^{38}$

\section{The need for a "sufficient scientific" basis for the SPS measure}

South Africa is required to ensure that any sanitary or phytosanitary measure is applied only to the extent necessary to protect human, animal or plant life or health, is based on scientific principles and is not maintained without sufficient scientific evidence, except as provided for in paragraph 7 of Article $5 .{ }^{39}$ Article 2.2 contains three separate requirements: (i) the requirement that SPS measures be applied only to the extent necessary to protect human, animal or plant life or health; (ii) the requirement that SPS measures be based on scientific principles; and (iii) the requirement that

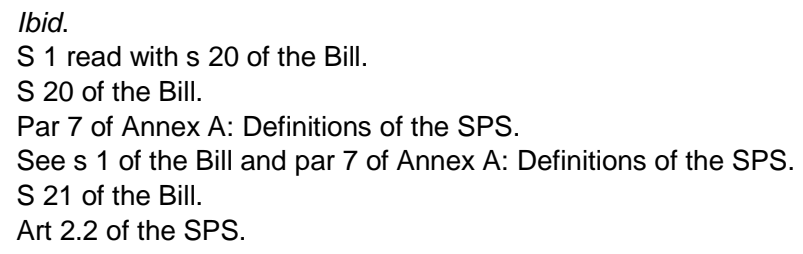


SPS measures not be maintained without sufficient scientific evidence. ${ }^{40}$ "Sufficiency" is a "relational concept". "Sufficiency" demands proof of an adequate relationship between two elements, in casu, between the SPS measure and the scientific evidence. ${ }^{42}$ Within the context of Article 2.2 of the SPS, "scientific" means that the evidence under consideration must be evidence adduced through scientific methods, excluding on this score, information not established through a scientific method. ${ }^{43}$ It has been held that the context of the word "sufficient" or, more generally, the phrase "maintained without sufficient scientific evidence" in Article 2.2, includes Article 5.1 as well as Articles 3.3 and 5.7 of the SPS. ${ }^{44}$ In essence, Article 2.2 "excludes not only insufficiently substantiated information, but also such things as a non-demonstrated hypothesis". ${ }^{45}$ It follows then that Article 2.2 informs Article 5.1 of the SPS: the elements that define the basic obligation set out in Article 2.2 impart meaning to Article 5.1. ${ }^{46}$ According to Article 5.1, Members must ensure that their sanitary or phytosanitary measures are based on an appropriate assessment that takes into consideration, risks to human, animal or plant life or health, as well as affording due consideration to risk assessment techniques developed by the relevant international organizations. Therefore, a contravention of Article 5.1 invariably means a contravention of Article 2.2 of the SPS. ${ }^{47}$ In the same vein Article 3.3 is relevant to the determination of "sufficient scientific evidence" in that it authorises a Member to introduce or maintain a phytosanitary measure which results in a higher level of protection than would be achieved by an international standard, if there is a scientific justification, subject to the proviso that such measure must not be in conflict with any other provision of the SPS. This means that there is a "scientific justification" for a SPS measure, within the meaning of Article 3.3, if there is a rational relationship between the impugned SPS measure and the available scientific information. ${ }^{48}$ It is also common cause that Article 5.7 of the SPS Agreement, to which Article 2.2 explicitly refers, is part and parcel of the "context of the latter provision and must be considered in the interpretation of the obligation not to maintain a SPS measure without sufficient scientific evidence". ${ }^{49}$ This is because Article 5.7 permits the provisional imposition of a phytosanitary measure in instances whereby there is insufficient scientific evidence.

In this regard, the Bill aligns itself with the SPS by providing that phytosanitary measures to prevent the introduction, establishment and

40 Panel Report European Communities Measures affecting the Approval and Marketing of Biotech Products, DS291, adopted by 21 November 2006 par 7.1424.

41 WTO Appellate Body Report, Japan Measures affecting Agricultural Products DS76 (hereinafter "Appellate Body Report, Japan Agricultural"), adopted on 19 March 1999, par 73.

42 Appellate Body Report, Japan Agricultural par 73.

43 WTO Panel Report, Japan Measures affecting the Importation of Apples DS245 (hereinafter "Panel Report, Japan Apples"), adopted 10 December 2003, par 8.92-8.93.

44 Appellate Body Report, Japan Agricultural par 74.

45 Panel Report, Japan Apples par 8.92-8.93.

46 Appellate Body Report, EC Hormones fn 12, par 180

47 WTO Appellate Body Report, Australia Salmon par 138.

4 Appellate Body Report, Japan Agricultural par 79.

49 Appellate Body Report, Japan Agricultural par 80. 
spread of regulated pests must be based on existing international standards or be technically justified based on pest risk analysis. ${ }^{50}$ "Technically justified" means justified based on conclusions reached by using an appropriate pest risk analysis or, where applicable, another comparable examination and evaluation of available scientific information. ${ }^{51}$ Therefore, the Bill clearly places "sufficient science" at the heart of any phytosanitary measure by requiring that an "appropriate pest risk analysis" be conducted. It follows then that the Bill creates a clear textual basis for a "science" based phytosanitary regime in the manner contemplated by the SPS.

It appears that the requirement for "sufficient science" was implied in the Act although this approach lent itself to ambiguity and uncertainty. The Act merely provides for the prescribing of control measures via the Gazette in order to prevent and combat the spreading of pathogens, red-billed quelea, insects and exotic animals that must be complied with or carried out by a user of land..$^{52}$ The National Control Measure 110 of 27 January 1984 is also silent on the "sufficient science" requirement. ${ }^{53}$ This means that the Act gave the Minister carte blanche power to prescribe phytosanitary measures without an express requirement that such measures must be based at the very least, scientific principles and "sufficient science". It has been opined that measures, which are arbitrary and lack a scientific basis denote an underlying protectionist objective. ${ }^{54}$

Concomitant with the requirement for a scientific basis, the Bill, like its forerunner, the SPS, requires that a "pest risk analysis" be conducted as the basis of any SPS measure. ${ }^{55}$ The SPS defines a "risk assessment" as the evaluation of the likelihood of entry, establishment or spread of a pest or disease within the territory of an importing Member according to the sanitary or phytosanitary measures that might be applied, and of the associated potential biological and economic consequences; or the evaluation of the potential for adverse effects on human or animal health arising from the presence of additives, contaminants, toxins or disease-causing organisms in food, beverages or feedstuffs. ${ }^{56}$ This means that where the relevant scientific evidence is adequate to conduct a risk assessment, as defined in Annex A of the SPS, a WTO Member may take a SPS measure "only if it is based on a risk assessment in accordance with Article 5.1 and that SPS measure is also subject to the obligations in Article 2.2". ${ }^{57}$ In the assessment of risks, Members must take into account available scientific evidence; relevant processes and production methods; relevant inspection, sampling and

$\mathrm{S} 12(2)$ of the Bill.

$\mathrm{S} 1$ of the Bill.

$S 6(1)$ of the Act.

53 GN 110 in GG 9047 of 27 January 1984: Agricultural Pests Act 36 of 1983: Control Measures.

54 Osiemo "The Last Frontier: Sanitary and Phytosanitary Standards and Technical Regulations as Non-Tariff Barriers in Intra-African Trade" 201523 African Journal of International and Comparative Law 174192.

$55 \mathrm{~S} 12$ and $\mathrm{S} 17$ of the Bill.

56 Par 4 of Annex A: Definitions of the SPS.

7 Appellate Body Report, Canada Continued Suspension of Obligations in the EC Hormones Dispute DS321, (hereinafter "Appellate Body Report, Canada Suspension"), adopted on 14 November 2008, par 674. 
testing methods; the prevalence of specific diseases or pests; the existence of pest- or disease-free areas; relevant ecological and environmental conditions; and quarantine or other treatment. ${ }^{58}$

In this regard, the Bill defines a "pest risk analysis" as the process of evaluating biological or other scientific and economic evidence to determine whether a pest should be regulated and the strength of any phytosanitary measures to be taken against it. ${ }^{59}$ It has been held that a risk assessment must do more than merely concluding that there is a possibility of entry, establishment or spread of diseases and the concomitant biological and economic consequences. ${ }^{60} \mathrm{~A}$ duly implemented risk assessment of this type must assess the "likelihood", that is, the "probability", of "entry, establishment or spread of diseases and associated biological and economic consequences". 61 The Bill's definition of a "pest risk analysis" is commendable because it entrenches the "science" based ethos of the SPS. This is because the Bill offers an apt and immediate illustration of the connection between Article 2.2 and Article 5.1 of the SPS in that it emphasises the need of a SPS measure to have a sufficient scientific basis based on a pest risk analysis. However, the Bill fails to capture the material aspects of a "risk assessment" in the manner contemplated by the SPS. The SPS requires "that a risk assessment must evaluate both the likelihood of entry, establishment or spread of a pest or disease within the territory of an importing Member according to the sanitary or phytosanitary measures that might be applied, and (author's own emphasis) the potential biological and economic consequences; or (author's own emphasis) the evaluation of the potential for adverse effects on the human or animal health arising from the presence of additives, toxins or disease-causing organisms in food, beverages or feedstuffs". ${ }^{2}$ In this way, the Bill does not cater for the adverse effects on human or animal health borne out of the "presence of additives or toxins or disease-carrying organisms in food, beverages or feedstuffs". Secondly, the Bill fails to capture the latent intricacies of a risk assessment as postulated in the SPS. This is because the SPS adds an additional requirement depending on the risk under consideration: ${ }^{63}$ On the one hand, for all risks emanating from the presence of additives, contaminants, toxins or disease-causing organisms in food, beverages or foodstuffs, it is the potential effects on human or animal life that must be assessed; on the other hand, for pest or diseases, the SPS distinguishes between two different forms of risk assessment, the likelihood of a pest or disease entering, establishing and spreading needs to be evaluated according to the SPS measure, which may be applied, that is, more than one measure may need to be evaluated. ${ }^{64}$

The requirement that a SPS measure is "based on" a risk assessment is a fundamental requirement that a "rational relationship" must exist between

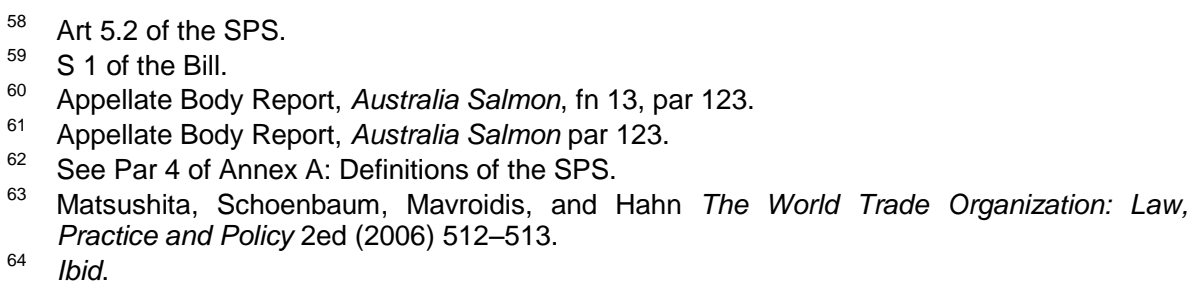


the measure and the "risk assessment". ${ }^{65}$ Article 5.1 and Article 2.2 of the SPS must be read together and, they collectively require that the results of the risk assessment must justify the SPS measure at stake ${ }^{66}$ In this way, it can be seen that the Bill mirrors the SPS in that the pest risk assessment is now a requirement of the regulatory framework of South Africa and also expressly establishes a connection between the strength (author's own emphasis) of the measure taken and the risk posed by the prohibited pest. Thus, it can be argued that the Bill ensures that there is a rational relationship between the phytosanitary measure and the risk assessment.

The SPS also provides that sanitary or phytosanitary measures, which conform to international standards, guidelines or recommendations, shall be deemed necessary to protect human, animal or plant life or health, and presumed to be consistent with the relevant provisions of this Agreement and of GATT 1994. ${ }^{67}$ The SPS further elaborates that all measures, which result in a level of sanitary or phytosanitary protection different from that which would be achieved by measures based on international standards, guidelines or recommendations shall not be inconsistent with any other provision of the SPS if there is a scientific justification (author's own emphasis), or as a consequence of the level of sanitary or phytosanitary protection a Member determines to be appropriate in accordance with the relevant provisions of paragraphs 1 through 8 of Article $5.2 .^{68}$ For the purposes of paragraph 3 of Article 3, there is a scientific justification if, on the basis of an examination and evaluation of available scientific information in conformity with the relevant provisions of this Agreement, a Member determines that the relevant international standards, guidelines or recommendations are not sufficient to achieve its appropriate level of sanitary or phytosanitary protection. ${ }^{69}$ In this respect, the Bill substantially complies with the SPS by providing that phytosanitary measures to prevent the introduction, establishment and spread of regulated pests must be based on existing international standards or be technically justified based on pest risk analysis. ${ }^{70}$ In this way, the Bill aptly captures the exception envisaged in Article 3.3 of the SPS in that it recognises as valid, phytosanitary measures that do not conform to "international standards" if they can be "technically justified". What is particularly significant here is that the departure from the "international standard" based on a "scientific justification" envisaged in Article 3.3 of the SPS, does not require that the Members comply with Article 5 of the SPS. ${ }^{71}$ It has been opined that the lack of scientific expertise and data collection significantly impede the ability of many developing countries to comply with the convoluted requirements for a risk assessment to justify their departure from international standards. ${ }^{72}$

65 WTO Appellate Body Report, European Communities Measures Concerning Meat and Meat Products (hereinafter "Appellate Body Report, EC Hormones"), adopted 13 February 1998, fn 12, par 193.

66 Appellate Body Report, EC Hormones par 193.

67 Art 3.2 of the SPS.

Art 3.3 of the SPS.

Fn 2 of the SPS.

$\mathrm{S} 12$ (2) of the Bill.

Matsushita et al The World Trade Organization: Law, Practice and Policy 507.

Prevost 200530 SAYIL 87. 
However, the problem with the "international standards" threshold in both the SPS and the Bill is that the participation of African institutions in the activities of the standard-setting organizations such as the World Organization for Animal Health (OIE) and the International Plant Protection Convention (IPPC) has been low. ${ }^{73}$ The majority of African countries cannot provide qualified personnel and lack the required skills to contribute in a meaningful way and this is exacerbated by a failure to reach a common ethos on SPS issues. ${ }^{74}$ These circumstances have caused Africa to be on the periphery of the legislative processes of emerging standards that impact significantly on African countries.

\section{The Bill and Article 5.7 of the SPS}

Article 5.7 of the SPS provides that in cases where relevant scientific evidence is insufficient, a Member may provisionally adopt sanitary or phytosanitary measures on the basis of available pertinent information, including that from the relevant international organizations as well as from sanitary or phytosanitary measures applied by other Members. ${ }^{76}$ In such circumstances, Members shall seek to obtain the additional information necessary for a more objective assessment of risk and review the sanitary or phytosanitary measure accordingly within a reasonable period of time. ${ }^{77}$ Thus, the applicability of Articles 2.2 and 5.1, on the one hand, and of Article 5.7, on the other hand, will depend on the adequacy of the scientific evidence. ${ }^{78}$ The Appellate Body has explained that the relevant scientific evidence will be considered "insufficient" for purposes of Article 5.7 "if the body of available scientific evidence does not allow, in quantitative or qualitative terms, the performance of an adequate assessment of risks as required under Article 5.1 and as defined in Annex A to the SPS". ${ }^{79}$ In this way, Article 5.7 constitutes "a qualified exemption from the obligation under 2.2 not to maintain SPS measures without sufficient scientific evidence" ${ }^{80} \mathrm{~A}$ wide and flexible interpretation of that obligation would nullify Article $5.7 .^{81}$ If the relevant scientific evidence is inadequate to conduct a risk assessment, a Member may take a provisional SPS measure on the basis provided in Article 5.7, but that Member must comply with the obligations espoused by that provision. ${ }^{82}$ In essence, characterising Article 5.7 as a qualified right rather than an exception means that if the impugned SPS measure was adopted and is maintained consistently within the cumulative requirements of Article 5.7, the situation is "as provided for in paragraph 7 of Article 5", and the duty to maintain SPS measures without sufficient scientific evidence

\footnotetext{
73 African Union InterAfrican Bureau for Animal Resources "Participation of African Nations in Sanitary and Phytosanitary Standard-setting Organisations" http://www.au-ibar.org/panspso (accessed 2016-03-08) 2.

74 lbid.

lbid.

Art 5.7 of the SPS.

lbid.

Appellate Body Report, Canada Suspension par 674

Ibid.

Appellate Body Report, Japan Agricultural par 80.

Ibid.

Appellate Body Report, Canada Suspension par 674.
} 
does not apply to the challenged measure. ${ }^{83}$ It must be borne in mind that Article 5.7 postulates a "provisional measure" and thus was not meant to justify a perpetual deviation from the "sufficient science rule" in Article 2.2.

In tandem with the Article 5.7 of the SPS, the Bill provides that in order to prevent the introduction, establishment and spread of regulated pests, the executive officer may implement "emergency and provisional measures" in relation to imports. ${ }^{84}$ An "emergency measure" means a phytosanitary measure established as a matter of urgency in a new or unexpected phytosanitary situation, which may or may not (author's own emphasis) be a provisional measure. ${ }^{85} \mathrm{~A}$ "provisional measure" on the other hand is defined as a phytosanitary regulation or procedure established without full technical justification owing to current lack of adequate information. ${ }^{86}$ It appears that the "provisional and emergency measures" act a dual mechanism to create the exception envisaged in Article 5.7 of the SPS. However, the Bill falls short of South Africa's obligations under the SPS in three significant respects; first, the Bill opens the door for the "emergency measure" contemplated in Article 5.7 to operate in perpetuity because the "emergency measure" may or may not (author's own emphasis) be provisional; second, the Bill does not require that the deviation from the norm must be based on available pertinent information applied by international organizations and other Members, ${ }^{87}$ and third, the Bill does not require that Members must obtain the additional information necessary for a more objective assessment of risk and review the sanitary or phytosanitary measure accordingly within a reasonable period of time ${ }^{88}$ What's more, the clumsy structure of the Bill in its provisions that create the exception to the "sufficient science" rule raises more interpretation problems. For instance, it is not clear in the Bill whether the word "provisional" is meant in the literal sense, that is to say, it denotes that such measure must be a temporary measure that is employed in circumstances whereby there is inadequate scientific justification or simply a name for a measure employed to address an urgent situation in the face of inadequate scientific justification without a limitation on the period of application. The latter interpretation could not have been the intention of the drafters of the legislation because it would violate the SPS. The resultant arduous task of interpretation would not be necessary if the Bill simply borrowed the appropriately drafted Article 5.7 of the SPS in toto, just as it has done with some of its provisions.

This triggers the debate on the precautionary principle. The WTO Appellate Body in EC Hormones held that the precautionary principle is reflected in the sixth paragraph of the preamble, Article 3.3 and Article 5.7 of the SPS. ${ }^{89}$ It was held that a "responsible, representative government may commonly act from the perspective of prudence and precaution" where there

83 Panel Report European Communities Measures Affecting the Approval and Marketing of Biotech Products DS291, adopted 21 November 2006 par 7.2974.

S 12(1)(c) of the Bill.

S 1 of the Bill.

86 Ibid.

See Art 5.7 of the SPS

88 Art 5.7 of the SPS.

89 Appellate Body Report, EC Hormones par 124. 
is a risk of irreparable harm to human health. ${ }^{90}$ In this way, it can be argued that the Bill propagates the precautionary approach and thus could be found to be in line with the SPS. This is because the Bill provides that in order to prevent the introduction, establishment and spread of regulated pests, the executive officer may, inter alia, "implement emergency and provisional measures in relation to imports". An "emergency measure" is defined as a phytosanitary measure established as a matter of urgency in a new or unexpected phytosanitary situation, and which may or may not be a provisional measure. ${ }^{92}$ The "provisional measure" is a phytosanitary regulation or procedure established without full technical justification owing to current lack of adequate information. ${ }^{93}$ In this regard, "technically justified" means justified on the basis of conclusions reached by using an appropriate pest risk analysis or, where applicable, another comparable examination and evaluation of available scientific information. This means that the Bill authorises the competent authority, in the absence of a pest risk analysis, to employ a temporary mechanism that addresses an unexpected phytosanitary situation. In simple terms, the competent authority can impose phytosanitary measures on the basis of insufficient scientific information. Therefore, these provisions of the Bill encapsulate the precautionary principle. However, the WTO Appellate Body has cautioned that the precautionary principle in Article 5.7 of the SPS does not operate as a tool to legitimise SPS measures that contravene the obligations of Members contemplated $s$ by the provisions of the SPS. ${ }^{94}$

\section{The burden on the "user of land"}

In simple terms, the "user of land" means an owner of the land. ${ }^{95}$ The Bill requires that the "user of land" who knows or suspects the presence of regulated pests on the land concerned must: immediately notify the executive officer or authority by the quickest practicable means; provide the executive officer with such further information as the executive officer may reasonably require, and take all reasonable measures to prevent the spread of the regulated pests. ${ }^{96}$ These obligations are cumulative and place too much responsibility on the "user of land". By way of comparison, in respect of "any person", the Bill only requires that such party, who has for the first time identified or recorded a pest to be present in the Republic immediately report such pest to the executive officer and/or authority. ${ }^{97}$ While it is accepted that is sound to place a more onerous duty on a "user of land" as the owner of the land, the Bill unduly shifts the responsibility to prevent the spread of regulated pests from the competent authority, the NPPOZA, to the "user of land". This places an unnecessary financial burden on the user of land. Significantly, the Bill goes against the pragmatic and sound approach

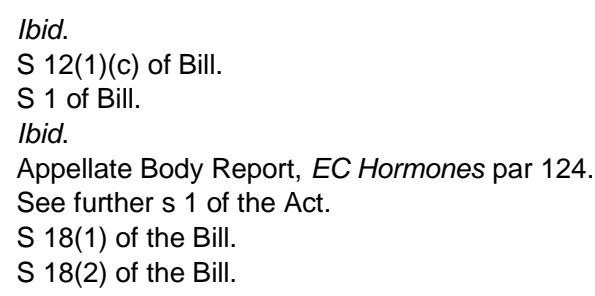


of the Control Notice on the Agricultural Pests Act. ${ }^{98}$ The Control Notice on the Agricultural Pests Act provides that a "user of land" only have a compulsory duty to report to the authority, the occurrence or suspected occurrence of prohibited insects and pathogens. ${ }^{99}$ It is suggested that the Bill must only require that the user of land should quickly notify the executive officer within a reasonable time, using practical means, and to provide information that is at their disposal. It must then be the duty of the executive officer to take all the necessary measures to prevent the spread of the regulated pest.

\section{CONCLUSION}

This paper critically examined the compatibility of the Bill with the salient aspects of the SPS. South Africa's regulatory framework has lagged behind its obligations under the SPS for too long. The Act by virtue of the fact that its promulgation occurred prior to the advent of the SPS, has proven wholly inadequate to address the challenges posed by prohibited pests. The Bill is seen as the panacea to address the glaring deficiencies of the Act. Upon closer inspection, it is found that the Bill has made significant strides in aligning South Africa's regulatory framework with the SPS. This is because it has been found that the Bill explicitly establishes the requirement that the new phytosanitary regime is based on "scientific principles". In the same vein, it has also been found that the Bill establishes the general rule that makes "sufficient science" the basis of any phytosanitary measure in conformity with South Africa's core obligations under the SPS.

However, fundamental deficiencies that could derail its primary mandate still hobble the Bill. In this regard, the paper argues that the Bill creates an ambiguity by including in the definition of "phytosanitary measures", those "measures, regulations or procedures that limit the economic impact of regulated non-quarantine pests", with no guidance on the relevant factors to be considered in this regard. Secondly, this paper finds that the Bill contravenes Article 5.7 of the SPS in that it provides for the implementation of the so-called "emergency and provisional measures" by the competent authority as an exception to the "sufficient science" rule, without any of the necessary safeguards created by Article 5.7. Lastly, the paper finds that the Bill has unduly shifted the primary burden of preventing the entry and establishment of a pest, from the competent authority to the "user of land".

98 GN 110 of GG 9047 of 1984-01-27: Agricultural Pests Act Control Measures.

99 S 8 of GN 110 of GG 9047 of 1984-01-27: Agricultural Pests Act Control Measures. 